\title{
Mikro Havza Ölçeğinde Erozyona Duyarlılık Parametreleri İle Bazı Toprak Özellikleri Arasındaki İlișkilerin Belirlenmesi
}

\author{
Fikret SAYGIN',* (D) \\ Orhan DENGiZ2 \\ 'Zir. Yük. Müh. Karadeniz Tarımsal Araștırma Enstitüsü, Samsun \\ ${ }^{2}$ Ondokuz Mayıs Üniversitesi, Ziraat Fakültesi, Toprak Bilimi ve Bitki Besleme Bölümü, Samsun
}

Serkan IÇ

*Sorumlu yazar e-posta (Corresponding author e-mail): fikretsaygin@gmail.com
Geliș tarihi (Received): 11.10 .2017
Kabul tarihi (Accepted): 11.07 .2019
DOI: $10.21657 /$ topraksu.654768

\section{Öz}

Hızlandırılmıș toprak erozyonunun olușumu, iklim ve toprak özelliklerine doğrudan bağımlı iken diğer faktörler erozyon olayının boyutunu ve yönünü belirlemektedir. Tahmin modellerine girdi olacak șekilde toprağın așınabilirlik karakterinin belirlenmesi, erozyon çalıșmalarında ilk adımı olușturmaktadır. Bu çalıșmanın amacı Türkiye'nin Doğu Karadeniz Bölgesi'nde, Bayburt ili sınırları içerisinde yer alan mikro havzaya ait ișlemeli tarım yapılan toprakların așınabilirliğini Evrensel Toprak Kayıp Eșitliği'nin alt bileșeni olan toprak așınım faktörü (USLE-K), dipersiyon oranı (DO) ve kil oranı (KO) göstergeleri ile ortaya koymaktır. Bu amaç doğrultusunda mikro havza içerisinde tarım arazilerinin yer aldığı 28 farklı noktadan toprak örnekleri alınmıștır. Laboratuvar çalıșmasından sonra elde edilen veriler dijital ortama aktarılmıș ve istatistiksel olarak test edilmiștir. Değerlendirme sonuçlarına göre mikro havza içerisinde yer alan ișlemeli tarım arazileri toprakların erozyona karșı hassasiyetleri değișkenlik göstermektedir. Toprakların USLE-K değerleri 0.070-0.580 $\mathrm{t} \mathrm{ha}^{-1} \mathrm{ha} \mathrm{MJ}^{-1} \mathrm{~h} \mathrm{~mm}^{-1}$ arasında değișirken KO değerleri ise 1.05-6.71 arasında değișim göstermiștir. Ayrıca DO değeri ise 5.81 ve 48.55 arasında değiștiği belirlenmiștir. USLE-K'ya göre tarım toprakların yaklașı \% 78.6'sı fazla ve çok fazla așınabilir sınıfa girerken, DO'a göre bu oran toprakların \% 50'si ve KO'nın büyük çoğunluğu erozyona karșı dayanaksız olup, bu topraklar nadas ve buğday tarımı yapılan alanlarda yer almaktadır.

Anahtar Kelimeler: Dispersiyon oranı, kil oranı, mikro havza, usle-k

\section{Relationships Between Erodibility And Some Soil Properties Of Soils In Micro Chatchment Scale}

\begin{abstract}
Generation of accelerated soil erosion depends on climate and soil properties directly, and also other factors determine its dimension and direction. Determination of soil erodibility characteristic as an input to predicting models is first step for soil erosion studies. The objective of this study was to reveal the erodibility of tillage soils by using soil erodibility factor (USLE-K), which has been the subfactor of Universal Soil Loss Equation (USLE), dispersion ratio (DR) and clay ratio (CR) indices on micro basin of Bayburt province located on Eastern Black Sea Region of Turkey. For this purpose, 28 soil samples were taken from different location points of cultivated land in micro basin. After laboratory studies, the data obtained were transferred to digital platform and tested statistically. According to evaluation results, the erosion sensitivity of micro basin soils was found to be different from each other. CR values varied between 1.05 and 6.71 while USLE-K values were calculated between 0.070 and $0.580 \mathrm{t} \mathrm{ha}^{-1}$ ha $\mathrm{MJ}^{-1} \mathrm{~h} \mathrm{~mm}^{-1}$. In addition, DR was also found between 5.81 and 48.55. According to USLE-K, 78.6\% of cultivated land soils was classified as high and very high erodible soil while more than half of soils
\end{abstract}


samples was classified low resist against to soil erosion. Moreover these soil samples were located on cultivated lands which have been used as fallow and wheat growth.

Key words: Dispersion ratio (dr), clay ratio (cr), micro basin, usle-k

\section{Gíriș}

Dünyaüzerinde pekçokinsan tarafındansadece bir üretim materyali olarak düșünülen toprak, bilim adamları tarafından yașayan ve yașatan, canlı, dinamik bir varlık olarak tanımlanmaktadır. Üç tarafı denizlerle çevrili olan ülkemizde mevcut toprak yapımızı arttıramayacağımız için sürdürülebilirliği sağlamak adına topraktan kayıpları en aza indirmek durumundayız. Bir bașka deyișle toprak olușumunu hızlandırmak mümkün olmadığı gibi, toprak varlığını suni olarak da artırmak mümkün değildir. Bu nedenle toprak konusunda diğer doğal kaynaklara oranla daha hassas olmak gerekir. İnsan, bitki ve hayvan hayatında önemli bir etkisi olan toprak, ekolojik, biyolojik, ekonomik ve kültürel fonksiyonları ile en önemli doğal kaynaklarımızdan birisidir. Ancak gerekli önlemlerin alınmaması, așırı ve yanlıș kullanım ve doğal etmenlere karșı etkili korunmaması nedeniyle giderek kaybolmaktadır (Kanar ve Dengiz., 2015).

Erozyon bir toprağın yüzeyinin su veya rüzgâr etkisiyle așınıma uğraması ve bulunduğu yerden geri dönüșümü mümkün olmayacak șekilde uzaklașmasıdır. Toprak așınımı, erozyonun doğal bir parçası olsa da, doğal kaynakların sürdürülebilirliğini tehdit etmesi açısından önemli bir sorun olarak ortaya çıkmaktadır (İmamoğlu vd., 2016).

Ülkemizdeki erozyon tehlikesinin boyutunun fazla olduğu ve uygulamaya yönelik her türlü bilimsel ve uzmansal, önleme veya koruma önlemleri alınmazsa, tehlike boyutlarının giderek artacağı ve özellikle toprak, topografya, su ve bitki örtüsü açısından geri-dönüșümsüz safhalara gelinebileceği açık bir șekilde bilinmektedir (Erpul ve Deviren-Saygın., 2012). Hızlandırılmıș toprak erozyonunun olușumu, iklim ve toprak özelliklerine doğrudan bağımlı iken, diğer faktörler erozyon olayının boyutunu ve yönünü belirlemektedir(Yakupoğlu ve Demirci, 2013). Kaldı ki, hızlandırımıș toprak erozyonu ile zaten kısıtlı olan kaynaklarımız, gelecekte büyük bir tehdit altında kalabilir (Erpul ve Deviren Saygın., 2012).
Toprağın așınabilirliği, toprak özellikleri ile arazi kullanım durumuna bağlı olarak değiștiği gibi, yağıșın erosivitesine göre de değișebilir (Kanar ve Dengiz, 2015). Bu sebeple toprağın așınmaya karșı direnci ya da erozyona karșı duyarlıı̆ıını ortaya koymak için, erozyona neden olabilecek parametreler ile toprak özellikleri arasındaki ilișkinin belirlenmesi gerekmektedir.

Bu çalıșmanın amacı Bayburt il sınırları içerisinde yer alan mikro havzası içerisinde yayılım gösteren toprakların așınabilirliğini Evrensel Toprak Kayıp Eșitliliği'nin alt bileșeni olan toprak așınım faktörü (USLE-K), dispersiyon oranı (DO) ve kil oranı (KO) gibi erozyon duyarlılık parametreleri ile topraklarının erozyona duyarlılık durumlarının belirlenmesi ve enterpolasyon modeller kullanılarak havza topraklarının erozyona hassasiyeti değerlendirilip haritalarının elde edilmesidir.

\section{MATERYAL VE YÖNTEM}

\section{Araștırma alanının genel tanımı \\ Coğrafi konum}

Bayburt ili $40^{\circ} 37^{1}$ Kuzey Enlemi ile $40^{\circ} 45^{\prime}$ Doğu boylamı, 39052ı Güney enlemi ile $39037^{1}$ batı boylamları arasında yer alır (Șekil 1). Doğusunda Erzurum, batısında Gümüșhane, kuzeyinde Trabzon ve Rize, güneyinde Erzincan illeri ile çevrili Anadolu'nun kuzey doğusunda Çoruh Nehri kenarında 3739 km2 yüzölçümüne sahiptir. Yaklașı 28499 ha alana sahip olan çalıșma alanı mikro havza, deniz seviyesinden 1450 m ile 2450 m arasında yüksekliğe sahiptir.

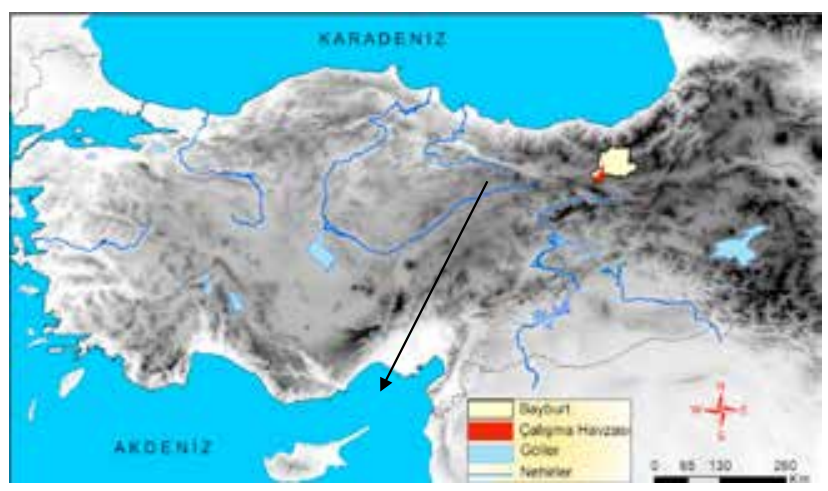

Șekil 1. Çalıșma alanına ait lokasyon haritası.

Figure 1. Location map of the study area. 


\section{İklim}

Bayburt ili Doğu Karadeniz iklimi ile Doğu Anadolu iklimi arasında, karasal özellikleri ağır basan bir geçiș iklimi hüküm sürmektedir. Kuzeyde uzanan Karadeniz Sıra Dağları, Karadeniz iklim etkilerinin bölgeye sarkmasını engellemektedir. Bu nedenle bölgede Doğu Anadolu'nun karasal ikliminin etkileri egemendir. Bu nedenle yazları sıcak ve kurak, kıșları ise soğuk ve kar yağıșlı geçmektedir. Bayburt ili yıllık ortalama sıcaklığı $6.9^{\circ} \mathrm{C}^{\prime}$ dir. Yıllık ortalama yağıș ise $442.1 \mathrm{~mm}$ 'dir.

\section{Arazi kullanımı arazi örtüsü}

Bitki örtüsü açısından çeșitlilik göstermesine rağmen, zengin değildir. Çalıșma alanına ait Corine 2012 sınıflamasına göre arazi örtüsü ve arazi kullanım türlerine ait dağılımı alanları ve oranları Çizelge 1' de ve Șekil 2' de verilmiștir. Havzanın yaklașık yarısından fazlasını meralık alanlar ile seyrek bitki alanları (\% 50.8) oluștururken, \% 47.2'lik alanları ise tarım arazileri olușturmaktadır.

\section{Yöntem}

Dispersiyon oranı: Süspansiyonda dispers edilmeden ölçülen silt+kil \% değerinin, mekanik analizde ölçülen silt+kil \% değerine oranlanmasıyla hesaplanmıștır (Lal, 1988).

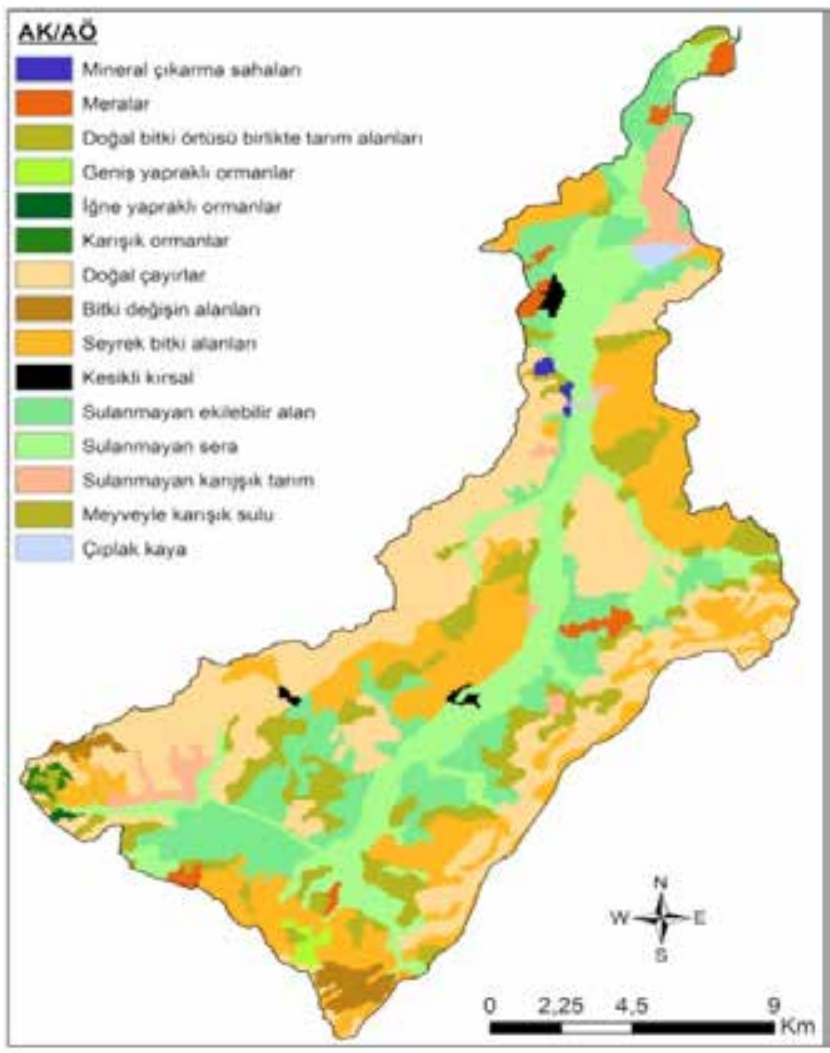

Șekil 2. Çalıșma alanı arazi kullanımı /arazi örtüsü haritası. Figure 2. Study area land use / land cover map.

Çizelge 1. Havzanın arazi kullanımı ve arazi örtüsü dağıım alanları ve oranları.

Table 1. Land use and land cover distribution areas and rates of the Basin.

\begin{tabular}{lcc}
\hline & & Alan \\
Arazi Kullanım-Arazi Örtüsü & ha & 0.1 \\
\cline { 2 - 3 } Endüstriyel veya ticari birimler & 32.4 & 0.2 \\
Mineral çıkarma sahaları & 64.0 & 1.5 \\
Meralar & 430.1 & 10.2 \\
Doğal bitki örtüsü birlikte tarım alanları & 2887.7 & 0.4 \\
Geniș yapraklı ormanlar & 118.3 & 0.1 \\
İğne yapraklı ormanlar & 28.4 & 0.3 \\
Karıșık ormanlar & 80.2 & 27.2 \\
Doğal çayırlar & 7729.0 & 1.4 \\
Bitki değișin alanları & 403.4 & 20.8 \\
Seyrek bitki alanları & 5902.5 & 0.5 \\
Kesikli kırsal & 130.4 & 15.6 \\
Sulanmayan ekilebilir alan & 4414.5 & 17.5 \\
Sulanmayan sera & 4960.4 & 3.0 \\
Sulanmayan karıjșık tarım & 860.2 & 1.2 \\
Meyveyle karıșık sulu & 332.1 & 0.4 \\
Çıplak kaya & 125.6 & 100.4 \\
\hline Toplam & 28499.0 & \\
\hline
\end{tabular}


Erodibilite (USLE-K) faktörü: K faktörü, her bir noktasal toprak örneği için yapılacak laboratuvar analizine dayalı olarak așağıdaki ampirik eșitlikten yararlanılarak belirlenir (Wischmeier and Smith, 1978).

USLE-K $=((2.17 \times 10-4) \times(M 1.14) \times(12-a)+3.25$ $x(b-2)+2.5 \times(c-3)) \times d$

Bu eșitlikten çıkan sonuçlara göre așağıdaki Çizelge 2'de USLE-K sınıf değeri belirlenir.

Çizelge 2. USLE- K sınıf değerleri.

Table 2. USLE-K class values.

\begin{tabular}{lcc}
\hline Tanım & Sınıf & Değer \\
\hline Çok az așınabilir topraklar & 1 & $0.00-0.05$ \\
Az așınabilir topraklar & 2 & $0.05-0.10$ \\
Orta derecede așınabilir topraklar & 3 & $0.10-0.20$ \\
Fazla așınabilir topraklar & 4 & $0.20-0.40$ \\
Çok fazla așınabilir topraklar & 5 & $0.40-0.60$ \\
\hline
\end{tabular}

Kil Oranı: Mekanik analizde ölçülen kum+silt \% değerinin, kil \% değerine oranlanmasıyla hesaplanmıștır (Özdemir, 2002). Tekstür: Toprakların tekstür sınıfları hidrometre yöntemi kullanılarak belirlenmiștir (Bouyoucous, 1951). Hidrolik iletkenlik: Toprakların hidrolik iletkenlik değerleri, su seviyesinin sabit olduğu hidrolik geçirgen setler yardımıyla hesaplanmıștır (Klute ve Dirksen, 1986). Toprakların hacim ağırlığı değerleri $100 \mathrm{~cm}^{3}$ hacimdeki çelik silindirler yardımıyla ve içerisinde alınan yapısı bozulmamıș toprak örnekleri $105^{\circ} \mathrm{C}$ sıcaklıkta etüvde kurutularak hesap yöntemiyle belirlenmiștir (Blake ve Hartge, 1986). Toprak organik maddesi, Walkley-Black yöntemiyle organik maddenin $1 \mathrm{~N} \mathrm{~K}_{2} \mathrm{Cr}_{2} \mathrm{O}_{7}$ ve $\mathrm{H}_{2} \mathrm{SO}_{2}$ ile oksitlenmesi ve $0.5 \mathrm{~N} \mathrm{FeSO}_{4} \cdot 7 \mathrm{H}_{2} \mathrm{O}$ ile titrimetrik olarak belirlenmiș ve \% olarak ifade edilmiștir (Kacar, 1994). Toplam Azot: Kjeldahl yöntemi ile belirlenmiștir (Bremner, 1965). Toprakların pH değerleri, 1:1 oranında hazırlanan toprak-su süspansiyonunda ve saturasyon çamurunda cam elektrotlu $\mathrm{pH}$ metre ile ölçülmüștür (Soil Survey Laboratory, 1992). Toprakların elektriksel iletkenlik değerleri, 1:1 oranında hazırlanan toprak-su süspansiyonunda ve saturasyon çamurunda elektriksel kondaktivite aleti ile belirlenmiștir (Richards, 1954). Toprakların kireç miktarı, serbest karbonatların Scheibler Kalsimetresi ile tayin edilip \% olarak belirlenmiștir (Kacar, 1994). Değișebilir katyonların belirlenmesi için, 3 g toprak örneği pH'sı 7 olan 25 ml $1 \mathrm{~N}$ amonyum asetat $\left(\mathrm{CH}_{3} \mathrm{COONH}_{4}\right)$ ile ekstrakte edilmiș ve filtre kâğıdından süzülmüștür. Süzükteki Na ve K atomik absorpsiyon spektrofotometresi ile Ca ve Mg 0.01M EDTA ile titre edilerek belirlenmiștir (Sağlam, 1997). Toprak örneklerinde fosfor, mavi renk metoduna göre belirlenmiștir (Olsen ve Sommers, 1982).

Toprak parametrelerinin değerinin alansal dağıımının belirlenmesinde en çok kullanılan enterpolasyon yöntemlerinden IDW, yöntemi kullanılmıștır. IDW enterpolasyon tekniği, determenistik bir yöntemdir (Özyazıcı vd, 2016). Deterministik teknikler enterpolasyon ișleminde matematiksel fonksiyonları kullanırken, Stochastic (jeostatistiksel) yöntemler tahmin ișlemindeki belirsizlik ve hataları da ortaya koyabilecek șekilde hem matematiksel hem de istatistiksel fonksiyonları dikkate alarak ișlem yapmaktadır. IDW enterpolasyon tekniği, enterpole edilecek yüzeyde yakındaki noktaların uzaktaki noktalardan daha fazla ağırlığa sahip olması esasına dayanır. Bu teknik, enterpole edilecek noktadan uzaklaștıkça ağırlığı da azaltan ve örnek noktaların ağılıklı ortalamasına göre bir yüzey enterpolasyonu yapar. En fazla yakındaki veri etkilenir. Yüzey ise yakınlık derecesine bağı olarak daha fazla ayrıntıya sahip olur (Arslanoğlu ve Özçelik, 2005). Çalıșma alanına ait elde edilen toprak analiz sonuçlarına ait tanımlayıcı istatistikler SPSS 12.0 paket programında yapılmıș, uygunluk sınıfların konumsal dağıım alanlarının belirlenmesinde ise ArcGIS 10.2v programları kullanılmıștır.

\section{BULGULAR VE TARTIȘMA}

\section{Havzaya ait temel coğrafi özellikler}

Havzanın temel coğrafi özelliklere yönelik olarak sayısal yükselti modeli, yükseklik, eğim ve bakı haritaları Șekil 3'te ve eğim ve bakı sınıflarına ait alansal ve oransal dağllım ise Çizelge $3^{\prime}$ te verilmiștir. Çalıșma alanı deniz seviyesinden 1621 m ile 2436 m yükseklik arasında olup, havzanın büyük bir çoğunluğu tepelik ve dağlık arazilerden olușmaktadır. Arazilerin özellikle vadi tabanlarında dağılım gösteren alanlarda eğim \% 0-6 arasında düzü düze yakın ve hafif eğimler \% 27'lik kısmı kaplarken, dik, çok dik ve sarp araziler ise toplam alanın yaklașık \% 44.3'lük kısmında yayılım göstermektedir. Havzanın yaklașık \%40'ık kısmı kuzey bakı ve kuzey bakının ara bakı sınıflarına ait iken, yine yaklașık üçte birlik (\% 31.6) kısım ise güney bakı ve güney bakının ara bakı sınıflarının dağılım gösterdiği görülmektedir. 
Çizelge 3. Araștırma alanı eğim ve bakı sınıflarına ait alansal ve oransal dağııım.

Table 3. Spatial and proportional distribution of the study area slope and view classes.

\begin{tabular}{ccccccc}
\hline \multirow{2}{*}{ Eğim (\%) } & \multicolumn{2}{c}{ Alan } & \multirow{2}{*}{ Bakı } & & \multicolumn{2}{c}{ Alan } \\
\cline { 2 - 3 } & ha & $\%$ & & Bäl & $\%$ \\
$2-6$ & 3609.6 & 12.7 & & Düz & 1747.1 & 6.1 \\
$6-12$ & 4066.4 & 14.3 & & Kuzey & 5602.0 & 19.7 \\
$12-20$ & 3494.8 & 12.3 & & Kuzeydoğu & 3835.9 & 13.5 \\
$20-30$ & 4724.8 & 16.6 & & Kuzeybatı & 1868.1 & 6.6 \\
$30-40$ & 5574.8 & 19.6 & & Güneydoğu & 2891.1 & 10.1 \\
$40+$ & 4040.7 & 14.2 & & Güney & 2675.8 & 9.4 \\
& 2987.9 & 10.5 & & Güneybatı & 3461.3 & 12.1 \\
& & & & Batı & 4526.2 & 15.9 \\
\hline Toplam & 28499.0 & 100.0 & Doğu & 3759.8 & 13.2 \\
\hline
\end{tabular}
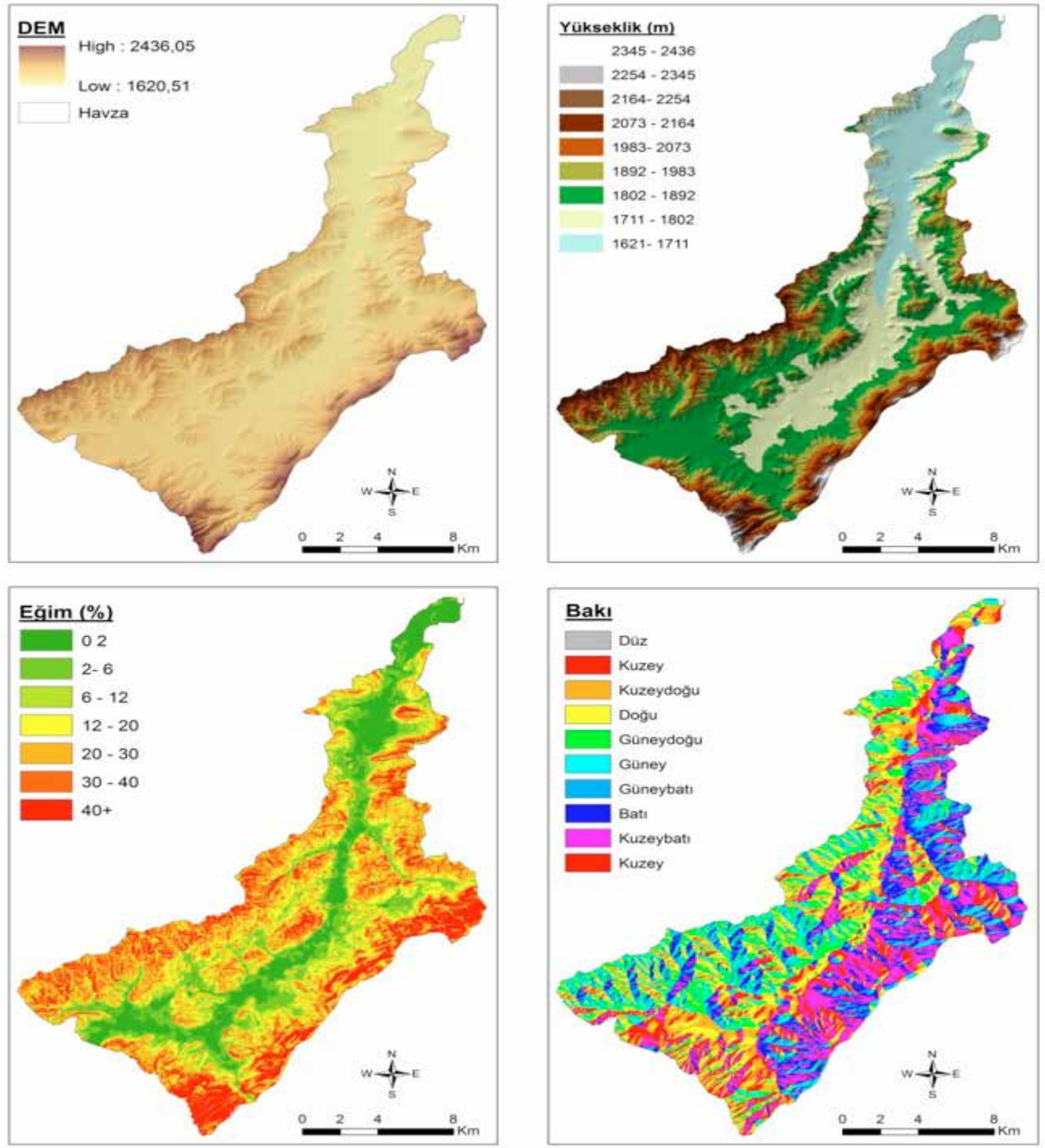

Șekil 3. Çalıșma alanı dem (sayısal yükselti modeli), yükseklik, eğim ve bakı haritaları.

Figure 3. The study area dem (digital elevation model), elevation, slope and views maps. 


\section{Toprak özellikleri ve istatistik analizleri}

Araștırma sahasından alınan 28 toprak örneğinin 22 adet farklı parametresi (DO, KO, USLE-K, kum, kil, silt, O.M, H.A, H.C, pH, EC, kireç, $\mathrm{P}, \mathrm{K}, \mathrm{Ca}, \mathrm{Mg}, \mathrm{Na}, \mathrm{N}$ ) incelenmiș ve bu özelliklerin tanımlayıcı istatistiksel hesaplamaları yapılmıștır (Çizelge 4). Toprak özelliklerindeki değișimlerin açıklanmasında önemli bir gösterge olarak kabul edilen değișkenlik katsayısını, aldığı değerlere göre düșük (<\%15), orta (\% 15-35) ve yüksek (>\%35) olarak sınıflandırmaktadır (Wilding, 1985; Sağlam, 2013 ve Mulla ve Mc Bratney, 2000). Bu çalıșmada OM, HA, $\mathrm{PH}, \mathrm{EC}, \mathrm{K}, \mathrm{Mg}, \mathrm{Na}, \mathrm{KO}$, USLE-K değișkenlik katsayıları düșük iken, kum, kil, Ca, DO ise yüksek değișkenlik özellikleri göstermektedir. Yapılan analizler sonucu elde edilen veriler ıșığında hazırlanan Çizelge 3.1'de görüldüğü üzere kum, kil, silt, EC, Ca, N, USLE-K normal dağılımlar sergilemektedir. $\mathrm{HA}$ ve $\mathrm{pH}$ sola çarpık dağılım özelliği gösterirken $\mathrm{OM}, \mathrm{HC}$, kireç, $\mathrm{P}, \mathrm{Mg}, \mathrm{Na}, \mathrm{DO}$ ve USLE-K ise sağa çarpık özellik göstermektedir. Carpıkık katsayılarının normal dağılımdan en uzak değer gösteren toprak özelliğinin Na olduğu, en yakın değer gösteren toprak özelliğinin ise kum özelliği olduğu görülmüștür.

Toprakların erozyon duyarlılık parametrelerinin değișim durumları incelendiğinde en yüksek değișkenlik dispersiyon oranında belirlenmiș olup 5.81 ile 48.55 arasında değișmektedir. Toprakların kil oranı ortalama 2.53 iken USLE-K değerleri 0.07 ile 0.58 arasında değișmektedir.

Çalıșma alanı topraklarının fiziksel özelliklerinden bünye dağılımı içerisinde kum $\% 12.8$ ile $\% 75.8$, kil $\% 12.9$ ile $\% 48.8$, silt ise \%10.5 ile \%39.9 arasında değișmektedir. Hacim ağırlığı ile hidrolik iletkenlik ise sırasıyla 1.17$1.59 \mathrm{gr} / \mathrm{cm} 3$ ve $1.37-25.59 \mathrm{~cm} / \mathrm{h}$ arasında değișmektedir. Toprakların reaksiyonu hafif asit ile hafif alkali arasında değișmekte olup ortalama 7.51 dir. Tüm topraklar tuzsuz olup, kireç \% 0.55 ile \% 17.52 arasında değișmektedir. Diğer bir toprağın önemli bir kimyasal özelliği olan organik madde ise çok fazla değișkenlik göstermekte ve \% 0.73 ile \%5.22 arasındadır. Toprakların verimlilik

Çizelge 4. Yüzey $(0-20 \mathrm{~cm})$ topraklarının fiziksel ve kimyasal özelliklerine ait tanımlayıcı istatistikleri.

Table 4. Descriptive statistics of the physical and chemical properties of the surface $(0-20 \mathrm{~cm})$ soil.

\begin{tabular}{lcccccccc}
\hline \multirow{2}{*}{ Parametreler } & \multicolumn{7}{c}{ Tanımsal İstatistik Özellikler } & \\
\cline { 2 - 8 } & Ort. & S.S & DK* & Varyans & EDD & EYD & Carpıklık* & Basıklık \\
\hline Kum \% & 40.70 & 16.30 & 62.91 & 265.99 & 12.8 & 75.80 & 0.379 & -0.564 \\
Kil \% & 32.66 & 10.55 & 35.86 & 111.44 & 12.9 & 48.83 & -0.415 & -0.715 \\
Silt \% & 26.62 & 8.19 & 29.39 & 67.22 & 10.5 & 39.90 & -0.327 & -0.647 \\
O.M \% & 2.05 & 0.98 & 4.49 & 0.97 & 0.72 & 5.22 & 1.449 & 2.877 \\
HA gr/cm & 1.41 & 0.11 & 0.42 & 0.01 & 1.17 & 1.59 & -0.591 & -0.414 \\
H.I cm/h & 7.78 & 6.94 & 24.22 & 48.28 & 1.37 & 25.59 & 1.336 & 0.830 \\
PH & 7.51 & 0.28 & 1.05 & 0.08 & 6.82 & 7.87 & -0.792 & -0.149 \\
EC dS m-1 & 0.45 & 0.11 & 0.47 & 0.02 & 0.23 & 0.69 & -0.171 & -0.150 \\
Kireç \% & 5.42 & 5.59 & 16.97 & 31.29 & 0.55 & 17.52 & 0.942 & -0.602 \\
P mg/kg & 5.79 & 4.82 & 21.29 & 23.31 & 1.81 & 23.10 & 2.511 & 6.409 \\
K me/100 gr & 0.62 & 0.30 & 1.336 & 0.09 & 0.13 & 1.47 & 0.892 & 0.809 \\
Ca me/100 gr & 26.67 & 9.03 & 36.68 & 81.51 & 8.87 & 45.56 & 0.371 & -0.251 \\
Mg me/100 gr & 4.30 & 2.58 & 10.23 & 6.66 & 0.94 & 11.18 & 1.247 & 1.511 \\
Na me/100 gr & 0.07 & 0.06 & 0.28 & 0.01 & 0.01 & 0.28 & 1.917 & 3.730 \\
N \% & 0.12 & 0.40 & 0.18 & 0.002 & 0.05 & 0.23 & 0.465 & 0.520 \\
DO & 18.20 & 11.20 & 42.74 & 125.49 & 5.81 & 48.55 & 1.322 & 0.879 \\
KO & 2.530 & 1.610 & 5.66 & 2.592 & 1.05 & 6.71 & 1.567 & 1.591 \\
USLE-K & 0.301 & 0.125 & 0.51 & 0.016 & 0.07 & 0.58 & 0.135 & -0.449 \\
\hline
\end{tabular}

*DK: Değișkenlik Katsayısı: < 15 = Düșük Değișkenlik. 15-35 = Orta Değișkenlik. n: 28-Örnek Sayısı, Ort.: Ortalama, S.S: Standart Sapma, EDD: En düșük değer, EYD: En yüksek değer, OM: organik Madde, EC: Elektiriksel Illetkenlik, DO: Dispersiyon Oranı, KO: Kil Oranı, USLE-K: Erodibilite faktörü, HA: Hacim Ağırlığı, Hi: Hidroik Iletkenlik., >35 = Yüksek Değișkenlik. ${ }^{*}$ Çarpıkıık: $0.5=$ Normal Dağıım. 0.5- $1.0=$ Veri setine karakter dönüșümü uygulanır. ÇK > $1.0 \rightarrow$ Logaritma dönüșümü uygulanır. 
özellikleri arasında fosfor, potasyum ve azot sırasıyla 1.82 ppm ile 23.11 ppm, potasyum 0.14 ile 1.47 me/100 gr ve azot ise \% 0.05 ile \% 0.23 arasında değișmektedir.

Toprakların ayrıca erozyon duyarlılık parametrelerinden olan DO, USLE-K ve $\mathrm{KO}$ analiz sonuçları ile diğer bazı temel toprak analiz sonuçları arasındaki ayrı ayrı ilișkilerine bakılmıștır. Bu ilișkilere ait korelasyon katsayıları ve önem düzeyleri Çizelge 5'te sunulmuștur. Analiz sonuçlarının normal dağılıp dağımadığına Kolmogorov-Spirnov testi SPSS (Karaatlı, 2010) ile kontrol edilmiștir. Toprak özellikleri arasındaki ilișki Spearman korelasyonu kullanılarak analiz edilmiș ve önemli korelasyonlar belirlenmiștir. Büyüköztürk (2009) korelasyon katsayısını 1.00 ile 0.70 arasında yüksek, 0.96 ile 0.30 arasında olması orta ve 0.29'un altında olmasını ise düșük düzeyde ilișki olduğunu șeklinde sınıflandırmıștır. Korelasyon analizi sonuçlarına göre DO, USLE-K, $\mathrm{KO}$ sonuçlarının diğer fiziksel toprak analiz sonuçlarıyla 45 korelasyon çiftinden 32 tanesi istatistiksel olarak anlamlı ( $\mathrm{p}$ : <0.05, $\mathrm{p}$ : <0.01) bulunmuștur. Erozyon duyarlılık parametreleri ile diğer toprak analizleri sonuçlarına bakıldığında ise 45 korelasyon çiftinden 24 tanesi istatistiksel olarak anlamlı (p: <0.05, p: <0.01) bulunmuștur. Ayrıca DO, USLE-K, KO ile diğer toprak analizleri ilișkisinde en yüksek pozitif korelasyon $\mathrm{KO}$ ile kum $(0,90 *)$ arasında görülürken en yüksek negatif

Çizelge 5. Toprak erozyon duyarlılık özellikleri ile bazı toprak özellikleri arasındaki korelasyon ilișkisi.

Table 5. Correlation relation between soil erosion sensitivity properties and some soil properties

\begin{tabular}{|c|c|c|c|}
\hline \multirow{2}{*}{ Toprak Özellikleri } & \multicolumn{3}{|c|}{ Erozyon Duyarlıık Parametreleri } \\
\hline & DO & USLE-K & $\mathrm{KO}$ \\
\hline Kum \% & 0.58 & $-0.87 * *$ & $0.90 *$ \\
\hline Kil \% & -0.54 & $0.68 *$ & $-1.00 * *$ \\
\hline Silt $\%$ & -0.42 & $0.83 * *$ & $-0.48 *$ \\
\hline O.M \% & -0.43 & $0.23 * *$ & -0.33 \\
\hline H.A gr/cm ${ }^{3}$ & 0.53 & $-0.57 * *$ & $0.60 *$ \\
\hline $\mathrm{H} . \mathrm{I} \mathrm{cm} / \mathrm{h}$ & 0.34 & $-0.53^{*}$ & 0.79 \\
\hline $\mathrm{pH}$ & 0.10 & $0.21 * *$ & $-0.07 *$ \\
\hline $\mathrm{EC} \mathrm{dS} \cdot \mathrm{m}^{-1}$ & -0.61 & $0.46 * *$ & -0.46 \\
\hline Kireç \% & -0.17 & $0.32 * *$ & $-0.35^{*}$ \\
\hline $\mathrm{P} \mathrm{mg/kg}$ & -0.20 & $-0.00 *$ & -0.14 \\
\hline $\mathrm{K}$ me/100 gr & -0.34 & $0.33^{* *}$ & $-0.44^{*}$ \\
\hline Ca me/100 gr & -0.59 & $0.71 * *$ & -0.64 \\
\hline Mg me/100 gr & -0.39 & $0.49 * *$ & $-0.72 *$ \\
\hline Na me/100 gr & -0.40 & $0.68 *$ & -0.71 \\
\hline N \% & -0.57 & $0.45 * *$ & $-0.39 *$ \\
\hline
\end{tabular}

korelasyon ise $\mathrm{KO}$ ile kil arasındadır $(-1,00 * *)$. Bu çalıșma göstermiștir ki USLE-K ve KO'nun kil içeriği ile olan ilișkilerinin negatif yönde önemli bulunması ve korelasyon katsayısının l'e yakın çıkması toprak așınabilirliğinin kil içeriğinden kuvvetli derecede etkilendiğini ve kil fraksiyonu miktarı diğerlerinden fazla olan toprakların așınıma karșı daha dirençli olduklarını göstermektedir.

\section{Toprakların erozyon duyarlılık özellikleri}

Havzanın erozyon duyarlılık özelliğinin belirlenmesi amacıyla alınan 28 toprak örneğinde kil oranı, dispersiyon oranı ve USLE-K değerleri belirlenmiștir. Havza topraklarına ait erozyon duyarlılık parametrelerine ait değerler Çizelge 6 ve haritaları ise Sekil 4' te verilmiștir.

USLE-K faktörünün tanımlanmasına yönelik olarak, birim erozyon parselinden elde edilen ortalama toprak kaybı olarak ifade dilmiștir. Bașkan ve Dengiz (2008), Ankara'nın Soğulca Havzası'nda geleneksel ve jeoistatistik yöntemlerle toprağın așınabilirlik (K faktörü) haritasını hazırlamıșlardır. Bu kapsamda çalıșma alanı içerisinde farklı kullanımlardan alanına toprak örneklerine ait așınabilirlik değerlerinde çok az ve orta așınabilir sınıflar yer almaz iken az așınabilir seviyede sadece B2 ve B19 nolu topraklar belirlenmiștir. Çalıșma alanı toprakların çoğu fazla ve çok fazla așınabilir sınıflarda yer almaktadır.

Dispersiyon oranı topraktaki doğal agregatların su ile temas ettiğinde çözülme (dispersleșme) derecesini gösteren bir göstergedir. Eğer topraktaki en küçük boyuta sahip agregatlar dahi suya dayanıklı ise, toprak erozyona dirençli olmaktadır. Bu sebeple toprağın erozyona eğilimini belirlemek amacı ile toprağın dispersiyon analizi yapılmıștır. Dispersiyon oranı \% 15'ten küçük olan topraklar erozyona karșı dayanıklıdırlar. Dispersiyon oranı \% 15'ten büyük olan topraklar ise erozyona karșı dayanıksız oldukları belirtilmektedir (Bryan, 1968). Çalıșma alanına ait toprakların dispersiyon oranı değerleri Çizelge 6'da verilmiștir. Havzadan alınan örneklerde yapılan analizler sonucu bulunan dispersiyon oranı değerleri \% 5.81 ile \% 48.55 arasında olduğu belirlenmiștir. Havzanın ortalama olarak dispersiyon oranı değeri ise \% 18.2 olarak bulunmuștur. 
Çizelge 6. Çalıșma alanına ait topak örneklerinin, arazi kullanım, koordinatları ve erozyon duyarlılık değerleri.

Table 6. Land use, coordinates and erosion susceptibility values of the soil samples of the study area.

\begin{tabular}{|c|c|c|c|c|c|c|}
\hline \multirow[t]{2}{*}{ Örnek No } & \multicolumn{2}{|c|}{$\begin{array}{c}\text { Koordinat } \\
\text { (37 Zone, UTM m) }\end{array}$} & \multirow[t]{2}{*}{ Arazi Kullanım } & \multirow{2}{*}{$\begin{array}{c}\text { Dispersiyon } \\
\text { Oranı }\end{array}$} & \multirow[t]{2}{*}{ Kil Oranı } & \multirow[t]{2}{*}{ USLE-K } \\
\hline & Doğu & Kuzey & & & & \\
\hline B0 & 563282 & 4427649 & Buğday & 10.41 & 1.71 & 0.27 \\
\hline B1 & 565854 & 4427769 & Buğday & 17.84 & 2.31 & 0.33 \\
\hline B2 & 562450 & 4429300 & Yonca & 38.79 & 6.71 & 0.09 \\
\hline B3 & 564548 & 4428888 & Buğday & 11.11 & 1.76 & 0.29 \\
\hline B4 & 568937 & 4426548 & Yonca & 13.48 & 1.76 & 0.33 \\
\hline B5 & 568556 & 4429289 & Yonca & 18.51 & 2.37 & 0.31 \\
\hline B6 & 567551 & 4431607 & Yonca & 26.90 & 4.97 & 0.21 \\
\hline B7 & 569840 & 4424658 & Yonca & 7.52 & 1.22 & 0.30 \\
\hline B8 & 570840 & 4422864 & Buğday & 8.66 & 2.38 & 0.22 \\
\hline B9 & 572285 & 4429490 & Nadas & 12.30 & 1.24 & 0.46 \\
\hline B10 & 572555 & 4431736 & Çayır & 11.60 & 1.11 & 0.32 \\
\hline B11 & 570905 & 4433418 & Korunga & 13.52 & 1.77 & 0.17 \\
\hline B12 & 574729 & 4434217 & Misır & 18.70 & 1.20 & 0.38 \\
\hline B13 & 578872 & 4435741 & Yonca & 8.24 & 1.55 & 0.38 \\
\hline B14 & 576746 & 4433330 & Nadas & 12.01 & 2.58 & 0.45 \\
\hline B15 & 581302 & 4437086 & Nadas & 15.87 & 2.96 & 0.17 \\
\hline B16 & 575307 & 4437800 & Nadas & 36.44 & 5.10 & 0.21 \\
\hline B17 & 574235 & 4439123 & Buğday & 12.34 & 3.36 & 0.23 \\
\hline B18 & 572621 & 4435300 & Buğday & 8.88 & 1.93 & 0.41 \\
\hline B19 & 578765 & 4437964 & Yonca & 48.55 & 6.66 & 0.07 \\
\hline B20 & 577569 & 4440645 & Buğday & 37.31 & 4.62 & 0.18 \\
\hline B2 1 & 576082 & 4444223 & Buğday & 21.32 & 1.52 & 0.58 \\
\hline B22 & 578251 & 4444858 & Nadas & 14.89 & 1.86 & 0.39 \\
\hline B23 & 579905 & 4447412 & Nadas & 8.65 & 1.56 & 0.39 \\
\hline B24 & 575631 & 4448758 & Buğday & 35.19 & 2.41 & 0.24 \\
\hline B25 & 578347 & 4450631 & Buğday & 19.82 & 1.05 & 0.49 \\
\hline B26 & 579659 & 4453441 & Buğday & 15.06 & 1.97 & 0.15 \\
\hline B27 & 581600 & 4455207 & Buğday & 5.81 & 1.22 & 0.43 \\
\hline
\end{tabular}
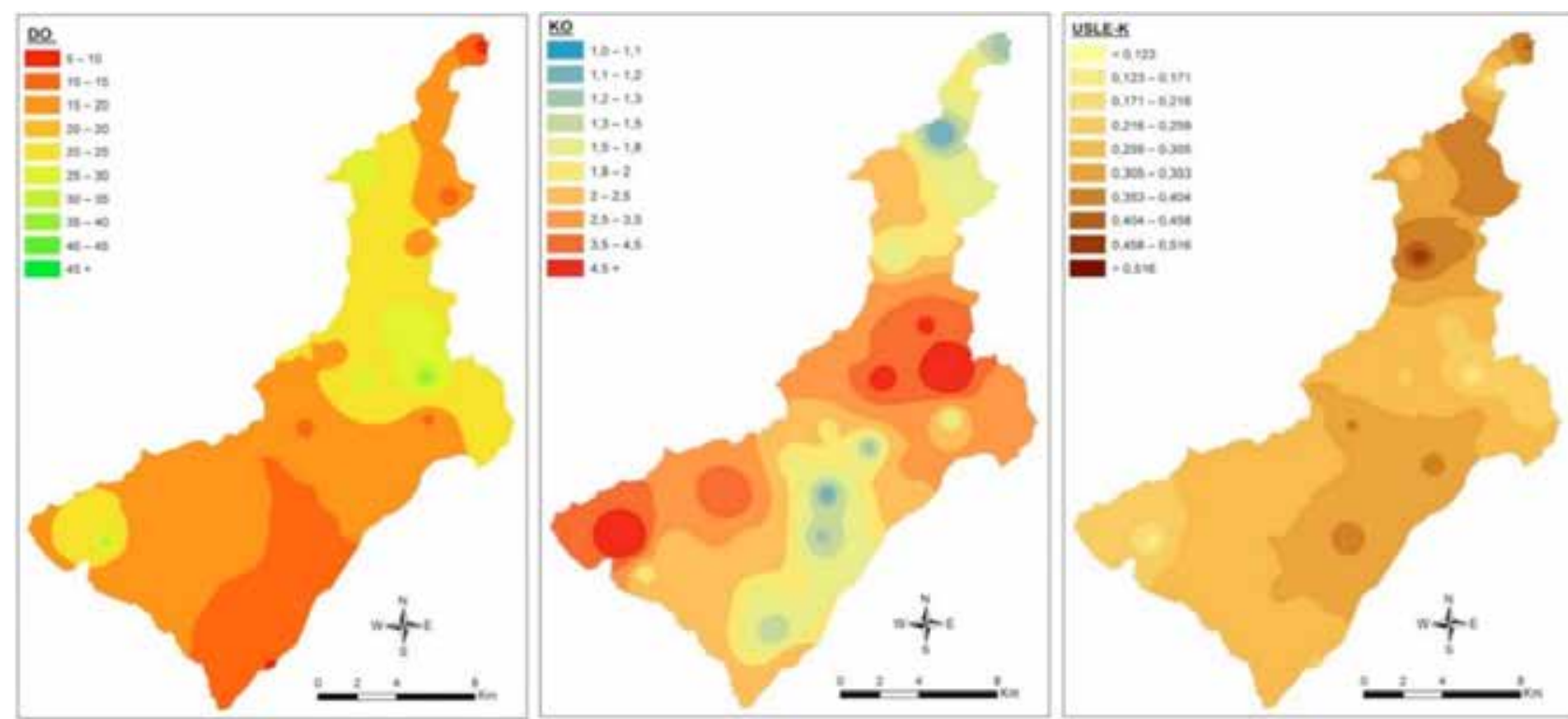

Șekil 4. Çalıșma alanı erozyon duyarlıık haritaları.

Figure 4. Study area erosion susceptibility maps. 


\section{SONUC̣LAR}

Havzadan arazi kullanım ve arazi örtüsü dikkate alınarak 28 adet toprak örneklerinde kil oranı, dispersiyon oranı, erodobilite, belirlenerek havza topraklarının erozyona hassaslıkları belirlenmiștir. Tüm duyarlılık sınıflarından da görülmektedir ki havza toprakları erozyona karșı büyük duyarlılıkları vardır. Bu durum özellikle eğimi yüksek olan, sığ toprakların yer aldığı alanlar ile tarım yapılan alanlarda daha da fazla duyarlı olduğu belirlenmiștir. Çalıșma alanında toprakların erozyon duyarlılıklarını azaltmak, agregatlașmayı artırmak ve $\mathrm{K}$ faktörü değerini düșürmek için toprak koruma yöntemi olarak bitkisel yöntemlere ağırık verilmelidir. Bitki ekim nöbeti uygulanmalı, toprağa organik madde ilave edilmelidir. Olanaklar ölçüsünde toprağı çabuk örten ve uzun süre toprak üzerinde kalan bitki türleri seçilmelidir.

\section{KAYNAKLAR}

Arslanoğlu M, Özçelik M (2005). Sayısal arazi yükseklik verilerinin iyileștirilmesi. TMMOB Harita ve Kadastro Mühendisleri Odası 10. Türkiye Harita Bilimsel ve Teknik Kurultayı, 28 Mart-1 Nisan, Ankara.

Bașkan O, Dengiz O (2008). Comparision of traditional and geostatistical methods to estimate soil erodibility factor, Arid Land Research and Management, 22: 29-45.

Blake GR, Hartge KH (1986). Bulk density and particle density. In: methods of soil analysis, part I, physical and mineralogical methods. Pp: 363-381. ASA and SSSA Agronomy Monograph, No:9, (2nd ed), Madison.

Bouyoucous GJ (1951). A Recalibration of the Hydrometer for Making Mechanical Analysis of Soil Agronomy Journal, 43: 434-438

Bremner JM (1965). Inorganic Forms of Nitrogen. Methods of Soil Analysis. Black, C.A. American Soc. Of Agron. Inc. Publ. Madison Wis., USA, 1197-1287.

Bryan RB (1968). The development, use and efficiency of indices of soil erodibility, Geoderma, 2: 5-26.

Büyüköztürk Ș (2009).Sosyal bilimler için veri analizi el kitabı. Ankara, Pegem Akademi.

Erpul G, Deviren-Saygın S (2012). Ülkemizdeki Toprak Erozyonu Sorunu Üzerine: Ne Yapmalı? Toprak Bilimi ve Bitki Besleme Dergisi, 1(1): 26-32.

İmamoğlu A, Bahadır M, Dengiz O (2016). Çorum Alaca Havzasında toprak erozyon duyarlıık faktörünün farklı enterpolasyon modelller kullanılarak konumsal dağılımlarının belirlenmesi, Toprak Su Dergisi, 5(1): (8-15).

Kacar B (1994). Bitki ve toprağın kimyasal analizleri III. (Toprak Analizleri). Ankara Üniversitesi Ziraat Fakültesi Eğitim Araștırma ve Geliștirme Fonu Yayınları, No. 3, Ankara.
Kanar E, Dengiz O (2015). Madendere Havzası topraklarında arazi kullanım/arazi örtüsü ile bazı erozyon duyarlıık indeksleri arasındaki ilișkinin belirlenmesi, Türkiye Tarımsal Araștırmalar Dergisi, 2: 15-27. ISSN: 2148-2306.

Karaatı M (2010). Verilerin düzenlenmesi ve gösterimi, Editör: KalayCl, Ș. SPSS uygulamalı çok değișkenli istatistik teknikleri, Asil Yayın Dağıtımı Ltd. Ști Ankara, pp. 2-47.

Klute A, Dirksen C (1986). Hydraulic conductivity and diffusivity. In: Klute, A. (Ed), Methods of Soil Analysis. Part 2. Agronomy 9: 687-732. Am. Soc. of Agron., Inc., Madison, Wisconsin, USA.

Lal R (1988). Soil erosion research methods. soil and water conservation society, Lucie Press, Florida.

Mulla DJ, McBratney AB (2000). Soil spatial variability. Handbook of soil science CRS Pres., pp. 321-352.

Olsen SR, Sommers LE (1982). Phosphorus methods of soil analysis. Part II. Chemical and microbiological properties. (Page et al.) p.403-430. ASA, SSSA, Madison, WI.

Özdemir N (2002). Toprak ve su koruma. OMÜ Zir. Fak. Yayınları No: 22, Samsun.

Özyazıcı MA, Dengiz O, Aydoğan M, Bayraklı B, Emel Kesim E, Urla Ö, Hakan Yıldız H, Ünal E (2016). Orta ve Doğu Karadeniz Bölgesi tarım topraklarının temel verimlilik düzeyleri ve alansal dağıımları. Anadolu Tarım Bilim. Derg. 31(1): 136-148.

Richards LA (1954). Diagnosis and Improvement of Saline and Alkaline Soils. U.S. Dept. Agr. Handbook, 60, 109. Riverside.

Sağlam M (2013). Çok değișkenli istatistiksel yöntemler ile toprak özelliklerinin gruplandırıması. Toprak Su Dergisi, 2(1): 7-14.

Sağlam, MT (1997). Toprak ve suyun kimyasal analiz yöntemleri. Trakya Üni. Ziraat Fak. Yayın No: 189, Ders Kitabı No: 5, 2. Baskı, Tekirdağ.

Soil Survey Staff. (1992). Procedures for collecting soil samples and methods of analysis for soil survey. Soil Surv. Invest. Rep. I. U.S. Gov. Print. Office, Washington D.C. USA.

Wilding LP (1985). Spatial variability: It's documentation, accommodation and implication to soil surveys. In: DR Nielsenand J Bouma (Eds.), Soil Spatial Variability, Pudoc, Wageningen, pp. 166-194.

Wischmeier WH, Smith DD (1978). Predicting rainfall erosion losses - a guide to conservation planning, Agriculture Handbook 537, United States Department of Agriculture, Washington DC, pp. 58.

Yakupoğlu T, Demirci D (2013). Kahramanmaraș-Narlı Ovası topraklarının erozyona duyarlııkları ile bazı toprak özellikleri arasındaki ilișkiler, Anadolu Tarım Bilimleri Dergisi, 28(1): 33-38. 